\title{
Recenzja
}

\section{Rada Europy a przemiany demokratyczne w państwach Europy Środkowej i Wschodniej w latach 1989-2009, red. Jerzy Jaskiernia, Wydawnictwo Adam Marszałek, Toruń 2010, ss. 864}

Książka Rada Europy a przemiany demokratyczne w państwach Europy Środkowej $i$ Wschodniej w latach 1989-2009 ukazała się nakładem Wydawnictwa Adam Marszałek w 2010 r. i zawiera dorobek naukowy Międzynarodowej Konferencji Naukowej „Europa Środkowa i Wschodnia jako obszar praworządności i praw człowieka - wpływ Rady Europy na przekształcenia systemowe w latach 1989-2009”. Konferencję, która odbyła się w 2009 r. w Szklarskiej Porębie, zorganizowało Międzynarodowe Centrum Prawa i Zarządzania Wyższej Szkoły Menedżerskiej w Legnicy we współpracy z Biurem Informacji Rady Europy, Fundacją Promocji Prawa Europejskiego w Warszawie oraz Fundacją Praw Podstawowych w Warszawie. Redakcji naukowej publikacji pokonferencyjnej podjął się prof. dr hab. Jerzy Jaskiernia, którego zainteresowania naukowe koncentrują się głównie wokół prawa konstytucyjnego, ale także problematyki praw człowieka i systemów ich ochrony.

We współczesnych stosunkach międzynarodowych istotną funkcję w kształtowaniu wizerunku państwa na arenie międzynarodowej pełni kwestia implementacji standardów dotyczących ochrony praw człowieka. Przez pryzmat poziomu tej ochrony i wdrażania standardów międzynarodowych ocenia się stopień demokratyzacji kraju. Innymi słowy, poziom ochrony praw człowieka stanowi obok wymogów ustrojowych jedno z kryteriów klasyfikowania państwa jako demokratyczne. Stąd też przemianom ustrojowym w Europie Środkowej i Wschodniej towarzyszyły kampanie na rzecz upowszechniania praw człowieka i zmian legislacyjnych w tej dziedzinie, które przyniosły wymierne efekty widoczne w regulacjach konstytucyjnych i ustawodawstwie zwykłym państw byłego bloku wschodniego. 20-lecie przemian demokratycznych stało się okazją do licznych podsumowań oraz upamiętnienia roli Rady Europy w procesie transformacji ustrojowej 
i promocji standardów demokratycznych oraz praw człowieka w państwach Europy Środkowej i Wschodniej. Recenzowana publikacja jest efektem tych podsumowań i, stanowiąc zarazem bardzo obszerny składający się z ponad 860 stron zbiór referatów, jest nie tylko źródłem cennej wiedzy, ale skłania ku przemyśleniu wyzwań stojących przed Radą Europy w przyszłości. Z tych względów problematyka podejmowana w książce jest aktualna, i to nie tylko z powodu oddziaływania Rady Europy na przemiany ustrojowe, ale także $\mathrm{z}$ racji aktywnego uczestnictwa Polski w jej pracach.

Publikacja zawiera 50 artykułów podzielonych pod względem tematycznym na cztery części. W pierwszej z nich zawarto artykuły dotyczące oddziaływania Rady Europy i tworzonego z jej inicjatywy prawa na przemiany demokratyczne w państwach członkowskich. Otwiera ją opracowanie Piotra A. Świtalskiego pod tytułem Rola Rady Europy w systemie organizacji międzynarodowych. Autor, Stały Przedstawiciel RP przy Radzie Europy, wskazuje na wzajemne powiązania funkcjonujących w Europie organizacji międzynarodowych (UE, OBWE i RE), a szczególnym analizom poddaje oddziaływanie Unii Europejskiej na wizerunek współczesnej Europy. Argumentuje, że nie bez znaczenia dla Rady Europy pozostaje kwestia uczestnictwa Rosji w jej pracach i stawia tezę, że przyszłość Rady Europy należy wiązać z działalnością Europejskiego Trybunału Praw Człowieka, stanowiącego jej wartość dodaną. Zagadnienia współpracy Rady Europy z Unią Europejską zostały także podjęte przez Stanisława Kaźmierczyka w artykule pod tytułem Wertykalność Unii Europejskiej w związku z horyzontalnościa Rady Europy jako zagadnienie metodologiczne i Elżbietę Dynię w opracowaniu zatytułowanym Współpraca Rady Europy z Uniq Europejska i jej wpływ na rozwój i spójność standardów międzynarodowych. Problem demokratyzacji struktur instytucjonalnych Unii Europejskiej budzi liczne kontrowersje w doktrynie, lecz autorzy dostrzegają wiodącą rolę Rady Europy przede wszystkim w kreowaniu standardów demokratycznych, rządów prawa i ochrony praw człowieka.

Druga część pracy, najbardziej obszerna, zawiera opracowania, których autorzy podjęli tematykę rozwoju systemu praw człowieka w Europie Środkowej i Wschodniej oraz roli Rady Europy w ich promocji. Otwiera ją artykuł Janusza Symonidesa, w którym zaprezentowano ewolucję systemu ochrony praw człowieka w Europie. W artykułach zawartych w tej części analizowane są zarówno standardy europejskie dotyczące konkretnych praw podmioto- 
wych (np. Wojciech Jasiński, Standard niezależnego i ustanowionego ustawa sadu w orzecznictwie Europejskiego Trybunału Praw Człowieka, Witold Sobczak, Wolność od tortur - czy istnieja standardy europejskie?) jak i te, które związane są z proceduralnymi aspektami dochodzenia naruszeń praw człowieka przed Trybunałem Strasburskim (np. Norbert Szczęch, Konsekwencje prawne objęcia RP kognicja Europejskiego Trybunału Praw Człowieka, Marta Kłopocka-Jasińska, Indywidualna skarga do Europejskiego Trybunału Praw Człowieka a krajowa skarga konstytucyjna - pilna potrzeba zmian).

W części trzeciej zawarto opracowania zawierające analizy wpływu Rady Europy na rozwój demokracji w państwach Europy Środkowej i Wschodniej i rozpoczyna ją artykuł Jerzego Oniszczuka zatytułowany Kantowska wolność człowieka: republika wolności versus demokracja. Zagadnienie pluralizmu politycznego w Polsce na tle wytycznych Rady Europy prezentuje w swoim opracowaniu Marek Chmaj, a europejskie standardy dotyczące administracji analizują Waldemar J. Wołpiuk, Krzysztof Gawkowski, Piotr Jankowski oraz Giovanni di Cosimo. Wolność słowa i ekspresji artystycznej jest tematem artykułów Ewy Nowak, Alicji Jaskierni i Jacka Sobczaka. Konkluzją większości referatów jest, że przechodzenie państw Europy Środkowej i Wschodniej transformacji ustrojowej nie odbyłoby się bez istotnego udziału Rady Europy, której standardy stanowiły „drogowskaz” przemian.

Część czwarta obejmuje opracowania, w których omówiono zagadnienia umacniania bezpieczeństwa w Europie Środkowej i Wschodniej w kontekście działań Rady Europy. Ze względu na fakt, że działalność Rady Europy w porównaniu do OBWE, ONZ i NATO w dziedzinie bezpieczeństwa nie jest jej priorytetem, artykuły zawarte w tej części są szczególnie interesujące. Tadeusz Iwiński wskazuje na rolę dyplomacji parlamentarnej Rady Europy (a szczególnie Zgromadzenia Parlamentarnego) w kwestii rozwiązywania konfliktów w państwach Europy Środkowej i Wschodniej, a Marek Ciecierski w opracowaniu zatytułowanym Rada Europy wobec wspótczesnych zagro$\dot{z} e n ́$ argumentuje, że „demokratyczne bezpieczeństwo” to obszar, w którym wartości promowane przez Radę Europy mogą stać się czynnikiem eliminującym zagrożenia już na wstępnym etapie ich powstawania.

Należy mieć na względzie, że recenzowana publikacja stanowi zbiór artykułów, a zatem jest wyrazem preferencji autorów co do określonej tematyki. Różnorodność podjętych zagadnień, a w szczególności ich międzynarodowy charakter jest atutem pracy i zachętą do pogłębiania zainteresowań nauko- 
wych czytelnika. Niewątpliwie skład zespołu autorskiego stanowi o interesującej treści tekstów, dlatego też wszystkim tym, którym tematyka publikacji jest bliska, z pełnym przekonaniem należy ją zarekomendować.

Olga Łachacz (Uniwersytet Warmińsko-Mazurski) 